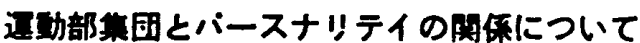

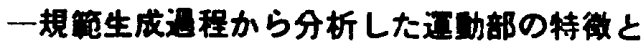
その機能との関保 第 2 報一

奈 良学芸大学○竹村昭

奈良女子大学丹羽劭昭 奈良女子大学付属中，高校 福 四 美津子

I. 目的

運動部を部の目標，および部における㚘船の生成過程 から分析し，それぞれの運動部の機能を检討して，その 特改を油出する。

II. 万法

1）調查の対象と時期：京都・大阪・兵庫・奈良各府 殞下の 9 大学に所感する，30 運動部の男・女約 300 名， および奈良県下の 9 高校，14 運動部の男・女約 170 名 をえらび，丝問紙と面接により，略昭 38 年 6 月から 8 月にわたつて調査した。

2）手統：集団の目標，および規筑の生成過程による 速動部の分析基準により，運動部を分類し，対象とする 部をえらび，かつ，運動部の機能を部員の結合状態や， 通動部の強さ（戦紿）などから分析した。

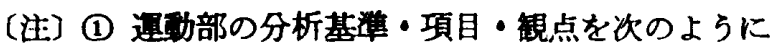
設定した．目棈の期準については，目標の内容上日標の 作られ方，および各部員の目標の受けとめ方を項目とし た。また，規簬生成過程の基淮に関しては，練習計画， キャブテン，および部則や部の約束ことの各設定方法を とりあげ，その各ィに部員の意志の反映の有無，設定 （選出）方法の内容，および成立する場合の最終決定者 の如何を項目とし，それぞれに钼点を設けた。

(2) 運動部の機能の 分折基淮・項目・観点を次のよ5 に設定した，部員の結合については，下級生と上䄲生， キャブテンと部員との関係をみるため，復従・親しさ ・尊敬を項目とし，それぞれについて，その程度を五 段階評価で行なつた．集団の霝囲気の項目では，試合に 負けた時に怒る，怤みる，励ます者を钼点として，高 压，温情，親和を項目とした，次に運動部の目標の成就 については，戦稓からみた部の強さを項目とし，最後 に，部員の結合と荤動部の目槚成就の重複した機能の基 淮については，練習への個人の加の程度と個人の判断 による部員全体の加の程度，および部則等の幕守の程 度を項目とし，それぞれについて，五段階評価を行なつ $\therefore=$

\section{III. 結果の要的}

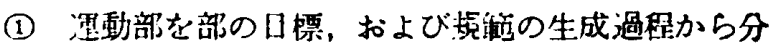
類するための項目を没定し，それぞれの観点から分析 し，運動部の：些質的支配力の所在によつて 矤型化する と下表のようになる。

\begin{tabular}{|c|c|}
\hline 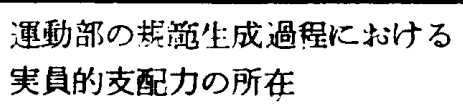 & 集団の特解 \\
\hline $\begin{array}{l}\text { 部員外者（伝統・部長・監督・ } \\
\text { コ一千等） }\end{array}$ & 部 \\
\hline 部員内主脳者と部員外者 & 部主畝 型 \\
\hline $\begin{array}{l}\text { 部員内主脳者（キャプテン・マ } \\
\text { ネージーー・上級生管） }\end{array}$ & 部内主媨型 \\
\hline 賁 & 員 \\
\hline
\end{tabular}

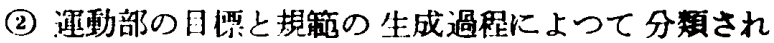
た運動部について，その機能を部員の結合状隹・部の日 標成就の程度（戦績からみた强さ）および部員結合と 目標成就の重複した機能の三つの基準から考察し，それ ぞれの運動部の特徵をあげると，下表のようになる。

\begin{tabular}{|c|c|c|c|c|c|c|}
\hline 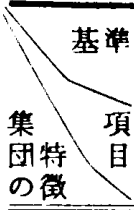 & $\begin{array}{l}\text { 部貝間の } \\
\text { 結合の性 } \\
\text { 筫 }\end{array}$ & 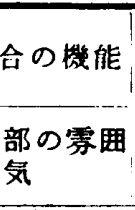 & 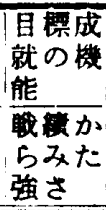 & $\begin{array}{l}\text { 部員結合 } \\
\text { 就の重復 } \\
\text { 練涡への } \\
\text { 参別の程 } \\
\text { 度 }\end{array}$ & $\begin{array}{l}\text { と目䏇成 } \\
\text { した機能 } \\
\text { 部則なとと } \\
\text { 渡守の程 }\end{array}$ & $\begin{array}{l}\text { 社会過 } \\
\text { 程の特 }\end{array}$ \\
\hline 部員外型 & $\begin{array}{l}\text { 下は上に } \\
\text { 対して権 } \\
\text { 力による } \\
\text { 腿众的結 } \\
\text { 合 }\end{array}$ & 高王的 & $\begin{array}{l}\text { 非常に } \\
\text { 強い }\end{array}$ & $\begin{array}{l}\text { 部員の } \\
\text { 加度は非 } \\
\text { 常に高い }\end{array}$ & $\begin{array}{l}\text { 非常に良 } \\
\text { 万守られ }\end{array}$ & 强的的 \\
\hline 主脳型 & $\begin{array}{l}\text { 下は上に } \\
\text { 対して権 } \\
\text { 咸によ } \\
\text { 龺放的結 } \\
\text { 合 }\end{array}$ & (親棈和的) & 強い & $\begin{array}{l}\text { 非常に高 } \\
\text { いかまた } \\
\text { はかなり } \\
\text { 高い }\end{array}$ & $\begin{array}{l}\text { 良く守ら } \\
れ て い る ~ \\
\text { かまたは } \\
\text { 普通 }\end{array}$ & 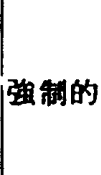 \\
\hline 部員型 & $\begin{array}{l}\text { 下は上に } \\
\text { 対して合 } \\
\text { 意に上る } \\
\text { 視和的結 } \\
\text { 合 }\end{array}$ & $\begin{array}{l}\text { 親和的 } \\
\text { (温情的) }\end{array}$ & 普通 & $\begin{array}{l}\text { 高いかま } \\
\text { たは普通 } \\
\text { 程度 }\end{array}$ & $\begin{array}{l}\text { 良く守ら } \\
\text { れている } \\
\text { かむたは } \\
\text { 普通 }\end{array}$ & 奶力的 \\
\hline
\end{tabular}

(3) 運動部の規筑生成過程からみた特挠と能の閏保

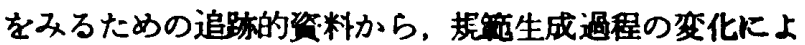
つて機能が若干变化する事例がみられた。 